Provided for non-commercial research and education use. Not for reproduction, distribution or commercial use.

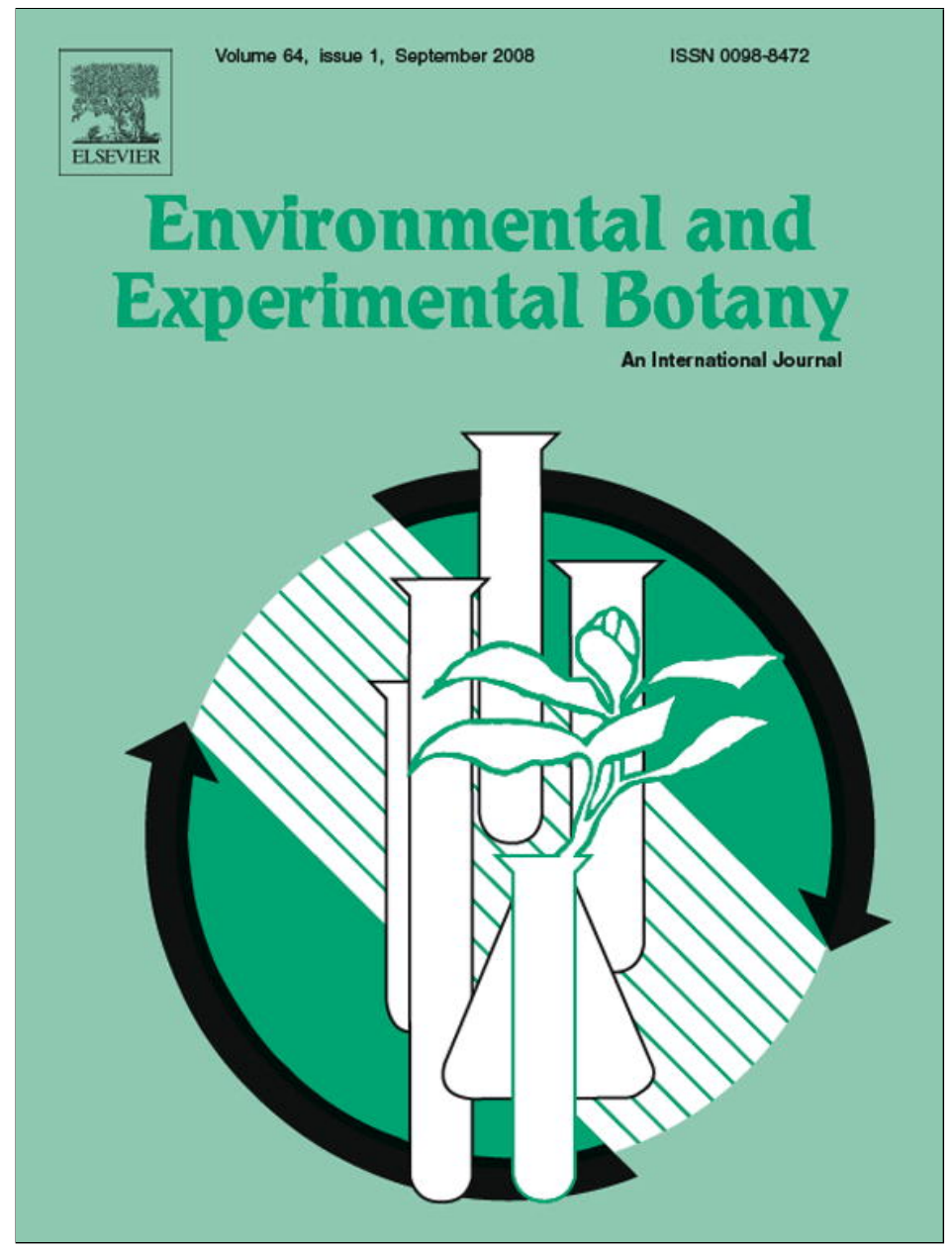

This article appeared in a journal published by Elsevier. The attached copy is furnished to the author for internal non-commercial research and education use, including for instruction at the authors institution and sharing with colleagues.

Other uses, including reproduction and distribution, or selling or licensing copies, or posting to personal, institutional or third party websites are prohibited.

In most cases authors are permitted to post their version of the article (e.g. in Word or Tex form) to their personal website or institutional repository. Authors requiring further information regarding Elsevier's archiving and manuscript policies are encouraged to visit:

http://www.elsevier.com/copyright 


\title{
Nutrient uptake by intact and disturbed roots of loblolly pine seedlings
}

\author{
Melissa S. Lucash ${ }^{\mathrm{a}}$, Ruth D. Yanai ${ }^{\mathrm{a}, *}$, J. Devereux Joslin ${ }^{\mathrm{b}}$ \\ a SUNY, College of Environmental Science and Forestry, Forest and Natural Resources Management, 1 Forestry Drive, Syracuse, NY 13210, USA \\ b Belowground Forest Research, Apartado 104-5655, Santa Elena de Monteverde, Puntarenas, Costa Rica
}

\section{A R T I C L E I N F O}

\section{Article history:}

Received 6 April 2007

Received in revised form 27 May 2008

Accepted 31 May 2008

\section{Keywords:}

Root disturbance

Efflux

Ion uptake

Loblolly pine seedling

\begin{abstract}
A B S T R A C T
Most measurements of nutrient uptake use either hydroponic systems or soil-grown roots that have been disturbed by excavation. The first objective of this study was to test how root excavation affects nitrate uptake. Rates of $\mathrm{NO}_{3}{ }^{-}$uptake by mycorrhizal loblolly pine (Pinus taeda $\mathrm{L}$.) seedlings were measured in intact sand-filled columns, hydroponics, and disturbed sand-filled columns. Total nitrate uptake in intact sand-filled columns was higher than in disturbed columns, indicating that disturbance lowers uptake. Transferring plants from the sand-filled columns to hydroponics had little effect on $\mathrm{NO}_{3}{ }^{-}$uptake beyond delaying uptake for an hour. The second objective of this study was to determine whether $\mathrm{NH}_{4}{ }^{+}, \mathrm{Ca}^{2+}, \mathrm{Mg}^{2+}$ and $\mathrm{K}^{+}$uptake could be studied using sand-filled columns, since previous studies had tested this method only for nitrate uptake. Uptake rates of $\mathrm{NH}_{4}{ }^{+}$and $\mathrm{K}^{+}$were positive, while $\mathrm{Ca}^{2+}$ and $\mathrm{Mg}^{2+}$ uptake rates were negative in intact sand-filled columns, indicating that net efflux may occur even without physical disturbance to the root system. The sand-filled column approach has some limitations, but holds promise for conducting nutrient uptake studies with minimal disturbance to the root system.
\end{abstract}

(c) 2008 Elsevier B.V. All rights reserved.

\section{Introduction}

Nutrient uptake from solution culture has been used extensively to quantify uptake in laboratory experiments (e.g. Epstein et al., 1963; Claasen and Barber, 1974; Marschner, 2002). In solutionculture systems, plants are often non-mycorrhizal, since growing ectomycorrhizal plants in hydroponics is difficult (Colpaert et al., 1999). Most plants in the field, however, are associated with mycorrhizal fungi, which have a significant impact on the mineral nutrition of plants (Smith and Read, 1997). More recently, the solution culture method has been adapted to measure nutrient uptake by mycorrhizal tree seedlings by growing the seedlings in soil to allow mycorrhizal development and then transferring them to hydroponic solution for uptake measurements (Rygiewicz et al., 1984; Bledsoe and Rygiewicz, 1986; Cumming, 1996; Constable et al., 2001). This method has also been used in the field where roots are excavated from soil but left attached to the tree. The roots are placed in a nutrient solution, from which nutrient depletion is measured over time (Rennenberg et al., 1996; BassiriRad et al., 1999; Lucash et al., 2005).

The problem with this approach is that removing the roots from the surrounding soil for uptake measurements may damage the roots and thereby reduce ion uptake. Although no studies

\footnotetext{
* Corresponding author.

E-mail address: rdyanai@syr.edu (R.D. Yanai).
}

to date have tested how excavating roots and transferring them to hydroponics affects their uptake rates, several studies have addressed how disturbance affects uptake. For example, gently rubbing roots can decrease their ATP content (Gronewald and Hanson, 1982), lower phosphorus influx (Gronewald and Hanson, 1982) and increase calcium influx (Rincon and Hanson, 1986). Mechanically striking roots without causing any visible damage can cause a short-term decline in net nitrate uptake and an increase in nitrate efflux (Aslam et al., 1996). Our previous attempts to measure uptake of recently excavated, intact roots resulted in considerable net efflux of some nutrients (McFarlane and Yanai, 2006; Lucash et al., 2007).

Excavating seedlings from soil also severs the extramatrical hyphae of mycorrhizae. Disrupting the extramatrical hyphae of vesicular-arbuscular mycorrhizae reduced $\mathrm{P}$ uptake by maize (McGonigle and Miller, 1996); no studies have addressed how excavation affects uptake by other nutrients or species.

In this study, we made use of a technique in which uptake is measured by monitoring the concentrations of nutrients in solution in a sand-filled column containing plant roots (Scholberg et al., 2002). This technique makes it possible to test how root excavation affects $\mathrm{NO}_{3}{ }^{-}$uptake by using a sequence of treatments to compare uptake from sand-filled columns with uptake in solution culture. In the first treatment, we measured $\mathrm{NO}_{3}{ }^{-}$uptake by mycorrhizal loblolly pine (Pinus taeda L.) seedlings in intact sand-filled columns. The second treatment was designed to measure the effect on root uptake of excavating the roots and severing 
mycorrhizal hyphae. It involved removing the seedlings from the sand-filled columns, placing the roots in nutrient solution and measuring their uptake using the hydroponic method. The two methods were repeated, which allowed us to determine how disturbance affects uptake in sand and to control for change over time in plant response.

The sand-filled column technique has been used to measure $\mathrm{NO}_{3}{ }^{-}$uptake by citrus seedlings (Scholberg et al., 2002) but has not been tested with other species or nutrients. Therefore we wanted to determine whether ammonium, calcium, magnesium and potassium uptake could be studied using this method. We measured $\mathrm{NH}_{4}{ }^{+}, \mathrm{Ca}^{2+}, \mathrm{Mg}^{2+}$ and $\mathrm{K}^{+}$uptake by loblolly pine seedlings using sand-filled columns and compared our uptake rates with those reported from other studies.

\section{Materials and methods}

\subsection{Greenhouse cultivation}

Loblolly pine seedlings were grown in a plantation for 1.5 years (East Tennessee Nursery, Delano, TN) before they were excavated and planted in sand-filled PVC pipes $(10 \mathrm{~cm}$ inner diameter, $15 \mathrm{~cm}$ tall) closed at the bottom with landscaping fabric. Sand-filled columns without plants served as controls. Columns were placed in the greenhouse in Syracuse, NY from January to June 2003. The seedlings were exposed to naturally occurring airborne and soilborne innoculum.

Plants were grown with supplemental lighting for approximately $12 \mathrm{~h}$ per day. During the uptake measurement period, light levels in the greenhouse were $360 \pm 58$ (S.E.) $\mu$ mol photons $\mathrm{m}^{-2} \mathrm{~s}^{-1}$ and average temperature was $25.5 \pm 0.3^{\circ} \mathrm{C}$. The columns were given $150 \mathrm{~mL}$ of water (approx. field capacity) daily. At harvest, the average total fresh seedling weight was $68 \pm 3 \mathrm{~g}$.

Mycorrhizal fungi found on the surface of the roots were identified by DNA sequencing (Applied Biosystems Automated 3730xl DNA Analyzer, Cornell University). The DNA sequences were matched to species using blast searching in GENBANK (http:// www.ncbi.nlm.nih.gov/BLAST/).

\subsection{Overview of sand-filled column method}

Prior to the beginning of the uptake measurements, $200 \mathrm{~mL}$ of dilute $(0.05 \times)$ Hoagland's nutrient solution (Hoagland and Arnon, 1950) was added to loblolly pine and control (sand only) columns for 1 week. The morning of the measurements, we placed PVC caps with valves on the base of the sand-filled columns and linked them via tubing to a valve manifold, vacuum pump and reservoir (Scholberg et al., 2002). After closing the valves at the base of each column, $300 \mathrm{~mL}$ of solution was added to each column. After $1 \mathrm{~h}$, the solution was removed by opening the valve and vacuuming each column at $-30 \mathrm{kPa}$ for 2 min.

After removal of the initial solution, a period of nutrient uptake measurement commenced. We added to each column $300 \mathrm{~mL}$ of nutrient solution, slightly $(10-20 \mathrm{~mL})$ more than field capacity. After $1 \mathrm{~h}$, the solution was vacuumed at $-30 \mathrm{kPa}$ into a reservoir and the leachate was weighed. A subsample $(8 \mathrm{~mL})$ was removed and frozen until analysis. The remaining solution was re-applied to the columns and nutrient uptake measured at 3 , 5,7 and $24 \mathrm{~h}$ by repeating the procedure described above. To minimize the formation of depletion zones and anaerobic conditions during the sampling intervals, the columns were drained every $30 \mathrm{~min}$ by gravity and the solution re-applied. In addition, the solution was vacuumed and re-applied on an hourly basis.

\subsection{Overview of hydroponic method}

For the hydroponic treatment, the seedlings and sand were removed from the columns. The seedlings were rinsed with DI water to remove any adhering sand and placed in Erlenmeyer flasks with $300 \mathrm{~mL}$ of dilute $(0.05 \times)$ Hoagland's solution. The solution was aerated by pumping ambient air through tubing to pipet tips inserted in the flasks. Rubber stoppers were placed inside each flask to reduce the volume of solution and thereby maximize the ratio of root surface area to solution volume. Six flasks with solution and stoppers served as controls. Samples $(8 \mathrm{~mL})$ were withdrawn and flasks weighed to determine solution volume at 1, 3, 5, 7 and $24 \mathrm{~h}$ intervals.

\subsection{Disturbance treatments}

To examine how disturbance affects nutrient uptake, plants were successively exposed to four treatments: (a) intact sand-filled columns, (b) hydroponics 1, (c) disturbed sand-filled columns, and (d) hydroponics 2. On the first day, we measured uptake of six plants using the sand-filled column method described above. This method allowed measurements of nutrient uptake by intact roots including the intact extramatrical hyphae of their mycorrhizal fungi. On the second day, we excavated the plants from the columns, placed them in aerated nutrient solution and measured uptake using the hydroponic method described above. This treatment simulated the transplant shock that occurs when intact roots are excavated and placed in nutrient solution. On day 3 , seedlings were removed from hydroponic solution and re-planted into the sand-filled columns to determine if uptake by disturbed roots differs between nutrient solution and sand culture. On day 4 , we re-excavated the plants, placed them into nutrient solution (hydroponics 2 ) and compared uptake to the previous hydroponic trial. This treatment allowed us to test for the effect of time or repeated experimentation on uptake. As a second measure of the effect of time, we measured uptake by a separate set of undisturbed plants $(n=6)$ for 4 days.

\subsection{Uptake of $\mathrm{NH}_{4}^{+}, \mathrm{Ca}^{2+}, \mathrm{Mg}^{2+}$ and $\mathrm{K}^{+}$}

During the first disturbance experiment we measured uptake in intact sand-filled columns using dilute $(0.05 \times)$ Hoagland's nutrient solution $\left(225 \mu \mathrm{mol} \mathrm{L}^{-1} \mathrm{Ca}^{2+}, 60 \mu \mathrm{mol} \mathrm{L}^{-1} \mathrm{Mg}^{2+}, 450 \mu \mathrm{mol} \mathrm{L}^{-1}\right.$ $\mathrm{K}^{+}$and $100 \mu \mathrm{mol} \mathrm{L}^{-1} \mathrm{NH}_{4}^{+}$). Sampling at 3, 5, 7, and $24 \mathrm{~h}$ was satisfactory for $\mathrm{Ca}^{2+} \mathrm{Mg}^{2+}$ and $\mathrm{K}^{+}$, but $\mathrm{NH}_{4}{ }^{+}$was depleted more rapidly. Therefore we conducted a follow-up experiment to measure $\mathrm{NH}_{4}{ }^{+}$ uptake by a separate set of seedlings $(n=3)$ in sand-filled columns at higher concentrations $\left(0.14 \times\right.$ Hoagland's, $\left.950 \mu \mathrm{mol} \mathrm{L}^{-1} \mathrm{NH}_{4}^{+}\right)$ with sampling at $0.5,1,1.5,2,2.5,3$ and $4 \mathrm{~h}$.

\subsection{Laboratory analyses and uptake calculations}

Nitrate and $\mathrm{NH}_{4}{ }^{+}$concentrations were determined by continuous flow analyzer (Bran and Luebbe, AA3), and base cations $\left(\mathrm{Ca}^{2+}\right.$, $\mathrm{Mg}^{2+}$, and $\mathrm{K}^{+}$) were analyzed using ICP emission spectrometer (Spectro Analytical Instruments, FMA-03). Nutrient uptake rates were calculated from changes over time in solution concentration ( $n=6$ plants). We calculated uptake rates for each time interval by computing the change in nutrient content of the solution (concentration times volume of leachate), taking into account volume changes due to sample removal. To correct for other sources and sinks of nutrients, the average change in nutrient content of controls at each time interval was subtracted from the change in columns containing seedlings. Recovery of nutrients in control columns was assessed by comparing nutrient contents of original and leachate nutrient solutions. 
At harvest, roots were severed from the shoots, cleaned and blotted dry. Uptake rates were expressed on the basis of fresh root weight. Uptake kinetics of $\mathrm{NO}_{3}{ }^{-}$were estimated using a Michaelis-Menten model. The slope $\left(I_{\mathrm{n}}\right)$ of the depletion vs. time curve was calculated for each time period and then fit to

$I_{\mathrm{n}}=\frac{I_{\max }\left(C_{0}-C_{\min }\right)}{K_{\mathrm{m}}+\left(C_{0}-C_{\min }\right)}$

where $I_{\max }$ is the maximum ion influx, $K_{\mathrm{m}}$ is the solution concentration at $(1 / 2) I_{\max }, C_{0}$ is the ion concentration, and $C_{\min }$ is the ion concentration when $I_{\mathrm{n}}$ is zero.

To determine how the methods for measuring $\mathrm{NO}_{3}{ }^{-}$uptake (intact columns, hydroponics 1 , disturbed columns, hydroponics 2 ) affected uptake rates, we analyzed the 7-h cumulative uptake in a repeated measures ANOVA with time as the repeated measure (SAS Institute, 1985). Since the interaction of time and treatment was significant at $\alpha=0.05$, we compared how the treatments varied with time using Student's multiple comparisons test. Within each treatment, we used linear regression to describe the relationship between uptake rate and nutrient concentration for $\mathrm{NO}_{3}{ }^{-}, \mathrm{NH}_{4}{ }^{+}$, $\mathrm{Ca}^{2+}, \mathrm{Mg}^{2+}$, and $\mathrm{K}^{+}$.

\section{Results}

\subsection{Identification of mycorrhizal fungi}

One simple, yellow morphotype with a thin mantle was found on all roots. DNA sequencing revealed that the fungus was Wilcoxina, which is known to establish mycorrhizal associations with loblolly pine in disturbed sites or in greenhouses.

\subsection{Evaluation of sand-filled column method for $\mathrm{NO}_{3}{ }^{-}$uptake}

We found that the $\mathrm{NO}_{3}{ }^{-}$concentration in the control columns was nearly constant over the 24 -h period and consistently higher than the concentrations in the columns containing seedlings (Fig. 1). Little of the applied $\mathrm{NO}_{3}{ }^{-}$remained in the column after vacuuming, as indicated by $94 \pm 0.7 \%$ (S.E.) recovery of the applied $\mathrm{NO}_{3}{ }^{-}$in the control columns.

\subsection{Intact vs. disturbed columns}

To evaluate the effect of excavation on uptake rates in sand, we compared uptake in sand-filled columns measured on the first day with uptake by these same plants after they were excavated

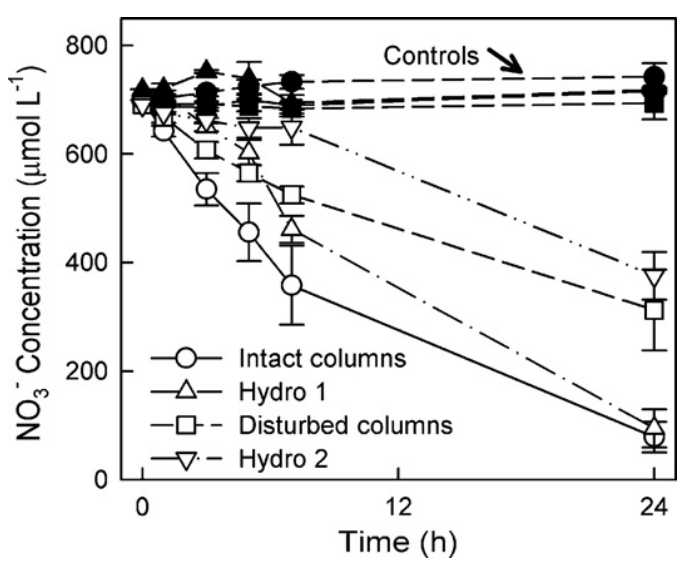

Fig. 1. Nitrate depletion curves of controls $(n=6)$ and loblolly pine seedlings $(n=6)$ exposed to four disturbance treatments. Vertical bars indicate standard errors.

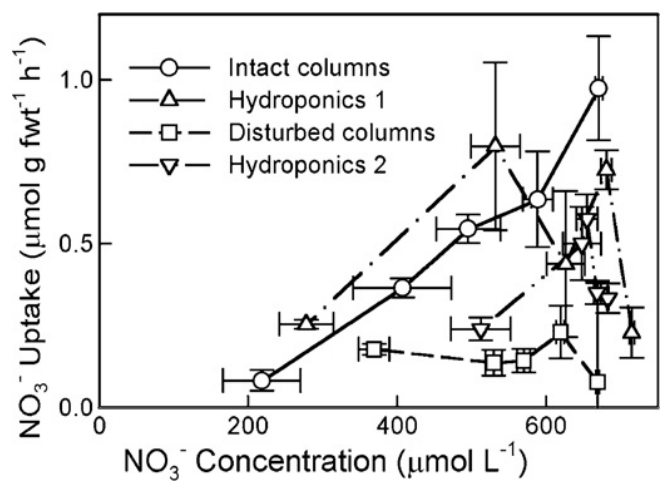

Fig. 2. Average net uptake of $\mathrm{NO}_{3}{ }^{-}$as a function of average concentration for loblolly seedlings exposed to four disturbance treatments $(n=6)$. Uptake rates were determined from changes over time in solution concentration and volume. Vertical bars indicate the standard error of uptake; horizontal bars show the standard error of solution concentration.

and repotted back into sand-filled columns on the third day. We predicted that the physical disturbance associated with excavating the seedlings and severing their extramatrical hyphae would negatively affect $\mathrm{NO}_{3}{ }^{-}$uptake.

As expected, disturbance lowered $\mathrm{NO}_{3}{ }^{-}$uptake (Fig. 2). At $7 \mathrm{~h}$, cumulative nitrate uptake was $10.6 \mu \mathrm{mol} \mathrm{gfwt}^{-1}$ in the intact sand-filled columns, while uptake was only $2.8 \mu \mathrm{mol} \mathrm{gfwt}^{-1}$ in the disturbed columns. By the end of the 24-h experiment, rates had slowed considerably in the intact columns, presumably because of the much lower concentrations attained $\left(78 \pm 29 \mu \mathrm{mol} \mathrm{L}^{-1}\right.$, Fig. 1). After being disturbed, plants depleted the solution to only $312 \pm 74 \mu \mathrm{mol} \mathrm{L}^{-1}$ in the 24 -h period (Fig. 1 ). These results indicate that disturbance lowers the ability of plants to take up $\mathrm{NO}_{3}$.

Concentrations in solution changed over the course of these experiments, due to uptake (or efflux) by the plants. Using the observed concentrations, we can describe how uptake varied with concentration. On an individual plant basis, three of the six plants showed Michaelis-Menten saturation (data not shown). Fig. 2 shows uptake as a function of concentration, with the initial (and highest) concentration on the right, and the observations progressing over time to the left. In the intact columns, average nitrate uptake was positively related to concentration $(p<0.0001)$. In the disturbed column treatment, plants had consistently low uptake rates, and thus showed little relationship of uptake to concentration $(p=0.8)$.

\subsection{Intact columns vs. hydroponic 1}

Since seedlings are commonly excavated from soil and then transferred to hydroponics to measure uptake rates, we compared $\mathrm{NO}_{3}{ }^{-}$uptake between intact sand-filled columns and the hydroponic 1 treatment, which we applied the following day.

The transfer of plants from sand culture to hydroponics initially caused a delay in $\mathrm{NO}_{3}{ }^{-}$uptake (Fig. 2). Uptake was higher in the intact columns than hydroponics at $1 \mathrm{~h}\left(1.0 \mu \mathrm{molgfwt} \mathrm{m}^{-1} \mathrm{~h}^{-1} \mathrm{vs}\right.$. $0.2 \mu \mathrm{mol} \mathrm{gfwt}^{-1} \mathrm{~h}^{-1}$ ). After the first hour, uptake rates were similar between plants in undisturbed intact columns and plants in hydroponics.

Because uptake rates were initially low, uptake was not related to concentration in this treatment ( $p=0.4$, Fig. 2$)$. The highest rates of uptake were observed in the second and fourth sampling intervals, which resulted in an erratic pattern of uptake with concentration (Fig. 2). 


\subsection{Temporal trends in uptake}

Since our experiments took several days to conduct, we repeated the hydroponic treatment to test whether uptake of our plants was declining over the duration of the experiments, independent of the nature of the treatments. Hydroponics 2 resulted in lower uptake than hydroponics 1 (Fig. 2). Reduced uptake could result from additional damage to the roots as they were transferred into and out of the disturbed column treatment, or uptake could be declining over the 4 days of the experiments, independent of our handling of them. To test whether $\mathrm{NO}_{3}{ }^{-}$ uptake declined over time in undisturbed plants, we measured uptake by an additional set of six plants in undisturbed sandfilled columns for 4 days. Average uptake was similar across days, but it was higher than for plants in undisturbed columns in the disturbance experiment $\left(0.9 \mu \mathrm{mol} \mathrm{gfwt}^{-1} \mathrm{~h}^{-1}\right.$ compared to $0.3 \mu \mathrm{mol} \mathrm{gfwt}^{-1} \mathrm{~h}^{-1}$ ), probably because we used different plants. Variability in nitrate uptake was only $0.12 \mu \mathrm{mol} \mathrm{gfwt}^{-1} \mathrm{~h}^{-1}$ (S.E.) among plants across the 4-day period. We conclude that the difference between hydroponics 1 and hydroponics 2 was due to the repeated disturbance to the roots rather than the duration of the experiment.

\subsection{Evaluation of sand-filled column method for $\mathrm{NH}_{4}{ }^{+}$uptake}

Analysis of $\mathrm{NH}_{4}{ }^{+}$concentrations in the undisturbed columns revealed rapid declines in the controls (data not shown). As a result, we measured uptake of $\mathrm{NH}_{4}{ }^{+}$at shorter time frames $(0-1 \mathrm{~h})$ than $\mathrm{NO}_{3}{ }^{-}(2 \mathrm{~h})$ and at higher concentrations $\left(950 \mu \mathrm{mol} \mathrm{L}^{-1}\right)$ than earlier experiments $\left(100 \mu \mathrm{mol} \mathrm{L}^{-1}\right)$. Under these conditions, the sand-filled column method showed high recovery of $\mathrm{NH}_{4}{ }^{+}$, with control recoveries consistently averaging $94 \%$. Plants depleted $\mathrm{NH}_{4}{ }^{+}$ in the columns, compared to the controls (Fig. 3). Plant uptake of $\mathrm{NH}_{4}{ }^{+}$was not significantly related to concentration ( $p=0.60$, Fig. 4 ), unlike uptake of $\mathrm{NO}_{3}{ }^{-}$, which declined as concentrations declined $(p<0.0001$, Fig. 2). Ammonium uptake rates over the first $4 \mathrm{~h}$ were approximately 1.4 times higher than $\mathrm{NO}_{3}{ }^{-}$uptake rates on a molar basis at similar concentrations (Figs. 2 and 4 ).

\subsection{Evaluation of sand-filled column method for uptake of base} cations

The undisturbed sand-filled columns showed high recovery of base cations in the controls; average recovery was $94 \%$ for $\mathrm{Ca}^{2+}$, $93 \%$ for $\mathrm{Mg}^{2+}$ and $93 \%$ for $\mathrm{K}^{+}$. The concentration of $\mathrm{Ca}^{2+}$ and $\mathrm{Mg}^{2+}$ was higher in the columns with plants than the controls (data not shown), due to high efflux rates by the plants during the first

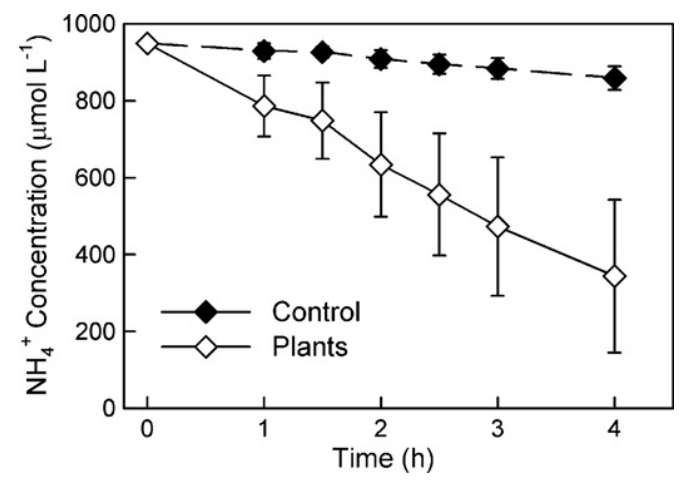

Fig. 3. Ammonium depletion curves of controls $(n=3)$ and in intact sand-filled columns containing loblolly pine seedlings $(n=3)$. Vertical bars indicate standard errors.

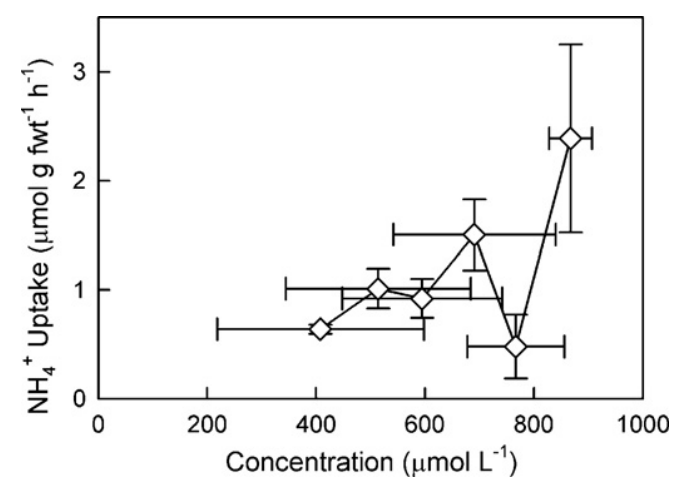

Fig. 4. Average net uptake of $\mathrm{NH}_{4}{ }^{+}$as a function of average concentration for loblolly seedlings grown in intact sand-filled columns. Uptake rates were determined from changes over time in solution concentration and volume, measured using intact roots $(n=3)$. Vertical bars indicate the standard error of uptake; horizontal bars show the standard error of solution concentration.

$3 \mathrm{~h}$ (Fig. 5). Subsequently, uptake was positive and concentrations declined over time. The concentration of $\mathrm{K}^{+}$was also higher in columns with plants than the controls except in the last time interval, but this was due to water uptake by the plants (data not shown); $\mathrm{K}^{+}$uptake was consistently positive (Fig. 5).
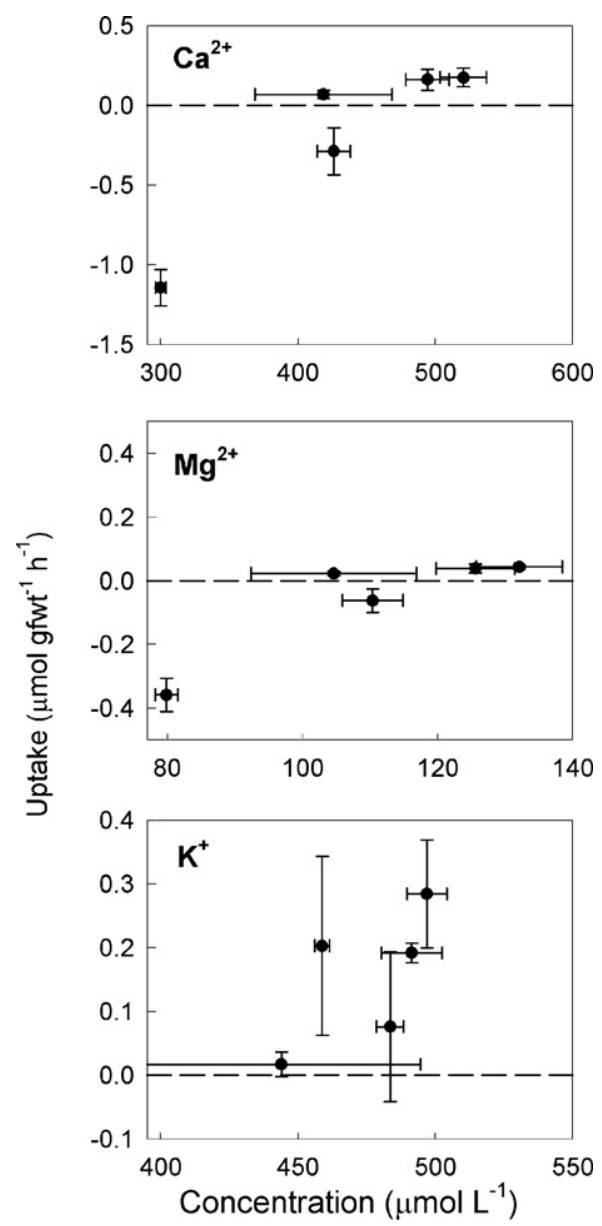

Fig. 5. Average net uptake of $\mathrm{Ca}^{2+}, \mathrm{Mg}^{2+}$ and $\mathrm{K}^{+}$as a function of average concentration for loblolly seedlings grown in intact sand-filled columns. Negative numbers indicate net efflux. Uptake rates were determined from changes over time in solution concentration, measured using intact roots $(n=6)$. Vertical bars indicate the standard error of uptake; horizontal bars show the standard error of solution concentration. 


\section{Discussion}

Disturbing the soil-root system of loblolly pine seedlings reduced cumulative $\mathrm{NO}_{3}{ }^{-}$uptake by $74 \%$; plants had consistently lower rates in the disturbed than intact columns across the range of concentrations used (Fig. 2). Other studies have shown that disturbance decreases $\mathrm{NO}_{3}{ }^{-}$uptake (Bloom and Sukrapanna, 1990) and increases $\mathrm{NO}_{3}{ }^{-}$efflux (Aslam et al., 1996). However, one study that used a disturbance regime similar to ours, whereby the researchers removed and homogenized the soil in the disturbed treatment, found that total $\mathrm{N}$ uptake of maize was higher in disturbed plants (McGonigle and Miller, 1996). Nitrogen mineralization rates may have increased in response to soil disturbance in their study, which would not be a problem in our experiment using sand.

Excavation of the root system may reduce uptake by physically damaging the roots or by disrupting uptake by mycorrhizal hyphae. In our study, as in others that excavated roots from soil and measured uptake (Rygiewicz et al., 1984; Gessler et al., 1998; BassiriRad et al., 1999), we could not distinguish the relative importance of root damage and mycorrhizal disruption in limiting uptake rates. By growing plants in nylon mesh cylinders that exclude roots but allow fungal hyphae to grow into the soil (Jasper et al., 1989), researchers have disrupted VAM hyphae without damaging the roots. This method has not yet been used in uptake experiments nor applied to ectomycorrhizal plants such as pines.

Since simply transferring roots between nutrient solutions can inhibit $\mathrm{NO}_{3}{ }^{-}$uptake for $6 \mathrm{~h}$ (Bloom and Sukrapanna, 1990), we expected that transfer of roots from soil to hydroponics would significantly reduce $\mathrm{NO}_{3}{ }^{-}$uptake. Transferring roots from soil to hydroponics caused a delay in $\mathrm{NO}_{3}{ }^{-}$uptake (Fig. 2), probably due to the disturbance associated with excavating the roots. After the first hour, uptake rates of plants in hydroponics were similar to rates of roots with intact mycorrhizae in sand-filled columns (Fig. 2). The absence of nutrient depletion zones in hydroponics may have compensated for the disruption of the uptake by extramatrical hyphae of mycorrhizae. These studies were conducted with loblolly pine in association with Wilcoxina, which is known to establish mycorrhizal associations with loblolly pine in disturbed sites or in greenhouses. The effects of disturbance on root uptake may differ with fungal species or strain.

Ammonium uptake rates measured using the sand-filled column method were similar to rates in most other studies. Ammonium uptake in our study $\left(0.5-2 \mu \mathrm{molgfwt}^{-1} \mathrm{~h}^{-1}\right)$ was similar to uptake by Norway spruce seedlings in sand culture $\left(0.3 \mu \mathrm{mol} \mathrm{gfwt}^{-1} \mathrm{~h}^{-1}\right.$, Eltrop and Marschner, 1996) and roots of Norway spruce $\left(0.5 \mu \mathrm{molgdwt}^{-1} \mathrm{~h}^{-1}\right.$, Gessler et al., 1998) and beech $\left(0.6 \mu \mathrm{mol} \mathrm{gdwt}^{-1} \mathrm{~h}^{-1}\right.$, Gessler et al., 1998) trees that were excavated and measured in nutrient solution. Assuming the ratio of fresh:dry weight of fine roots is 9 based on data from fine roots of loblolly pine in the field (unpublished data), our $\mathrm{NH}_{4}{ }^{+}$ uptake rates $\left(10 \mu \mathrm{molgdwt}-1 \mathrm{~h}^{-1}\right)$ were similar to uptake rates by loblolly pine seedlings ( $10 \mu \mathrm{molgdwt}^{-1} \mathrm{~h}^{-1}$, Constable et al., 2001 ) and eastern deciduous tree seedlings ( $12 \mu \mathrm{mol} \mathrm{gdwt}^{-1} \mathrm{~h}^{-1}$, Lajtha, 1994) in solution culture. Excised poplar roots also had uptake rates $\left(13 \mu \mathrm{molgdwt}^{-1} \mathrm{~h}^{-1}\right.$, Rothstein et al., 2000) that were comparable to our roots. In contrast, Scots pine seedlings ( $35 \mu \mathrm{molgdwt} \mathrm{m}^{-1} \mathrm{~h}^{-1}$, Boxman and Roelofs, 1987) and taega seedlings ( $20 \mu \mathrm{mol} \mathrm{gdwt}^{-1} \mathrm{~h}^{-1}$, Chapin et al., 1986) in solution culture had higher uptake rates than our loblolly pine roots.

Of the base cations, we observed positive uptake rates for $\mathrm{K}^{+}$ but not $\mathrm{Ca}^{2+}$ or $\mathrm{Mg}^{2+}$ (Fig. 5). Net uptake of $\mathrm{Ca}^{2+}$ and $\mathrm{Mg}^{2+}$ was negative in Scots pine (Boxman and Roelofs, 1987), Douglar-fir, Sitka spruce, and western hemlock (Rygiewicz et al., 1984) seedlings, except at high pH (Rygiewicz et al., 1984) and low $\mathrm{NO}_{3}{ }^{-}$concentrations (Boxman and Roelofs, 1987). In previous field experiments, we observed negative uptake of $\mathrm{Mg}^{2+}$ in hardwoods but found uptake was positive in conifers using roots of mature trees that were excavated and measured in nutrient solution (Lucash et al., 2007). Uptake of $\mathrm{Ca}^{2+}$ was negative in chestnut and white oak but not in the other species we studied. Although we observed positive uptake of $\mathrm{K}^{+}$in this study, we observed negative uptake rates of $\mathrm{K}^{+}$ by all species in our previous field experiments with roots of mature trees (Lucash et al., 2005, 2007). Net uptake of $\mathrm{K}^{+}$was also negative in Douglas-fir (Rygiewicz and Bledsoe, 1986; Rygiewicz et al., 1984), Sitka spruce (Rygiewicz et al., 1984), western hemlock (Rygiewicz et al., 1984) and Scots pine seedlings (Boxman and Roelofs, 1987). Even though net uptake rates are clearly not negative over the lifetime of the plant, efflux rates can exceed influx under certain experimental conditions. The timing of sampling (Scheurwater et al., 2000), plant nutritional status (Elliott et al., 1984; Oscarson et al., 1987; Clark et al., 2000), pretreatment nutrient concentrations (Rygiewicz and Bledsoe, 1986) and ion interactions (Dean-Drummond and Glass, 1983; Rygiewicz and Bledsoe, 1986) can all affect whether net efflux occurs. Although we know that transient fluxes may occur, more studies using methods that minimize disturbance to the root system are needed to understand the relative importance of efflux under field conditions (Lucash et al., 2007).

There are some additional drawbacks to the measurement of nutrient uptake using sand-filled columns. First, growing plants in sand rather than soil is clearly artificial, but adsorption of nutrients makes soil an intractable medium. In preliminary experiments, we found that $\mathrm{NO}_{3}{ }^{-}$recovery rates were only $83 \pm 14 \%$ in a mixture of sand and potting soil (Lucash, 2005). Even using sand-filled columns, sampling intervals and solution concentrations have to be chosen with care, as illustrated by our experience with adsorption of $\mathrm{NH}_{4}{ }^{+}$. Second, it is not possible to determine the exact concentration of nutrients at the root surface in sand as in solution culture, since concentrations will vary through the matrix as uptake (or efflux) occurs. We homogenized the concentrations every $1 / 2$ to $1 \mathrm{~h}$ by recirculating the nutrient solution, but this mixing and vacuuming may disturb roots, mycorrhizas and microbes. Third, if nitrification rates differ between the plant and the control columns, estimates of $\mathrm{NH}_{4}{ }^{+}$and $\mathrm{NO}_{3}{ }^{-}$uptake would be inaccurate. If these limitations can be overcome, the sand-filled column method may permit more accurate measurement of root uptake under field conditions than the hydroponic approaches.

\section{Conclusion}

The results of this study demonstrate that root excavation reduces $\mathrm{NO}_{3}{ }^{-}$uptake measured in sand-filled columns. Transferring plants from sand-filled columns to hydroponics has little effect on $\mathrm{NO}_{3}-$ uptake, suggesting that rates in hydroponics may be representative of rates observed in a soil matrix. Net uptake rates of $\mathrm{Ca}$ and $\mathrm{Mg}$ were negative in intact sand-filled columns, indicating that efflux rates may not be solely due to physical disturbance. Future studies should quantify efflux rates to more accurately estimate net uptake at the root scale. Unlike hydroponic studies which use excavated roots, the sand-filled column technique allows researchers to measure nutrient uptake with only minor disturbance to the root system.

\section{Acknowledgements}

We thank Johannes Scholberg for introducing us to the sandfilled column method and helping troubleshoot our initial attempts to use it. Oscar Abelleira, Megan Newhouse, Liz Schwartz, Don Bickelhaupt, Myriam Adam, and Adrienne Graham provided technical assistance. We also thank Russ Briggs for use of his autoanalyzer 
and Dave Eissenstat for his help in designing the disturbance experiment. Financial support was provided by the National Science Foundation through grants DEB-0087263 and 9211768.

\section{References}

Aslam, M., Travis, R.L., Rains, D.W., Huffaker, R.C., 1996. Effect of root perturbation and excision on nitrate influx and efflux in barley (Hordeum vulgare) seedlings. Physiol. Plant. 97, 425-432.

BassiriRad, H.H., Prior, S.A., Norby, R.J., Rogers, H.H., 1999. A field method of determining $\mathrm{NH}_{4}{ }^{+}$and $\mathrm{NO}_{3}{ }^{-}$uptake kinetics in intact roots: effects of $\mathrm{CO}_{2}$ enrichment on trees and crop species. Plant Soil 217, 195-204.

Bledsoe, C.S., Rygiewicz, P.T., 1986. Ectomycorrhizae affect ionic balance during ammonium uptake by Douglas-fir roots. New Phytol. 102, 271-283.

Bloom, A.J., Sukrapanna, S.S., 1990. Effects of exposure to ammonium and transplant shock upon the induction of nitrate absorption. Plant Physiol. 94 $85-90$.

Boxman, A.W., Roelofs, J.G.M., 1987. Some effects of nitrate versus ammonium nutrition on the nutrient fluxes in Pinus sylvestris seedlings. Effects of mycorrhizal infection. Can. J. Bot. 66, 1091-1097.

Chapin, F.S.I., Van Cleve, K., Tryon, P.R., 1986. Relationship of ion absorption to growth rate in taiga trees. Oecologia 69, 238-242.

Claasen, N., Barber, S.A., 1974. A method for characterizing the relation between nutrient concentration and flux into roots of intact plants. Plant Physiol. 54 564-568.

Clark, G.T., Dunlop, J., Phung, H.T., 2000. Phosphate absorption by Arabidopsis thaliana: interactions between phosphorus status and inhibition by arsenate. Aust. J. Plant Phys. 27, 959-965.

Colpaert, J.V., Van Tichelen, K.K., Van Assche, J.A., Van Laere, A., 1999. Short-term phosphorus uptake rates in mycorrhizal and non-mycorrhizal roots of intact Pinus sylvestris seedlings. New Phytol. 143, 589-597.

Constable, J.V.H., BassiriRad, H., Lussenhop, J., Zerihun, A., 2001. Influence of elevated $\mathrm{CO}_{2}$ and mycorrhizae on nitrogen acquisition: contrasting responses in Pinus taeda and Liquidambar styraciflua. Tree Physiol. 21, 83-91.

Cumming, J.R., 1996. Phosphate-limitation physiology in ectomycorrhizal pitch pine (Pinus rigida) seedlings. Tree Physiol. 16, 977-983.

Dean-Drummond, C.E., Glass, A.D.M., 1983. Short term studies of nitrate uptake into barley plants using ion-specific electrodes and ${ }^{36} \mathrm{ClO}_{3}{ }^{-}$II. Regulation of $\mathrm{NO}_{3}$ efflux by $\mathrm{NH}_{4}{ }^{+}$. Plant Physiol. 73, 105-110.

Elliott, G.C., Lynch, J., Lauchli, A., 1984. Influx and efflux of P in roots of intact maize plants. Plant Physiol. 76, 336-341.

Eltrop, L., Marschner, H., 1996. Growth and mineral nutrition of non-mycorrhizal and mycorrhizal Norway spruce (Picea abies) seedlings grown in semi-hydroponic sand culture. I. Growth and mineral nutrient uptake in plants supplied with different forms of nitrogen. New Phytol. 133, 469-478.

Epstein, E., Schmid, W.E., Rains, D.W., 1963. Significance and technique of shortterm experiments on solute absorption by plant tissue. Plant Cell Physiol. 4 79-84.

Gessler, A., Schneider, S., Von Sengbusch, D., Weber, P., Hanemann, U., Huber, C Rothe, A., Kreutzer, K., Rennenberg, H., 1998. Field and laboratory experiments on net uptake of nitrate and ammonium by the roots of spruce (Picea abies) and beech (Fagus sylvatica) trees. New Phytol. 138, 275-285.

Gronewald, J.W., Hanson, J.B., 1982. Adenine nucleotide content of corn roots as affected by injury and subsequent washing. Plant Physiol. 69, 1252-1256.

Hoagland, D.R., Arnon, D.I., 1950. The Water Culture Method of Growing Plants Without Soil. California Agriculture Experiment Station.

Jasper, D.A., Abbott, L.K., Robson, A.D., 1989. Soil disturbance reduces the infectivity of external hyphae of vesicular-arbuscular mycorrhizal fungi. New Phytol. 112, 93-99.

Lajtha, K., 1994. Nutrient uptake in eastern deciduous tree seedlings. Plant Soil 160, 193-199.

Lucash, M.S., Eissenstat, D.M., Yanai, R.D., Joslin, J.D., 2007. Estimating nutrient uptake by mature tree roots under field conditions: challenges and opportunities. Trees 21, 593-603.

Lucash, M.S., 2005. Methods for measuring nutrient uptake rates of intact roots of seedlings and mature trees. Ph.D. Dissertation. Department of Forest and Natural Resources Management. State University of New York College of Environmental Science and Forestry, $114 \mathrm{pp}$.

Lucash, M.S., Joslin, J.D., Yanai, R.D., 2005. Temporal variation in nutrient uptake capacity by intact roots of mature loblolly pine. Plant Soil 272, 253-262.

Marschner, H., 2002. Mineral Nutrition of Higher Plants. Academic Press, London.

McFarlane, K.J., Yanai, R.D., 2006. Measuring nitrogen and phosphorus uptake by intact roots of mature Acer saccharum Marsh., Pinus resinosa Ait., and Picea abies L.) Karst. Plant Soil 279, 163-172.

McGonigle, T.P., Miller, M.H., 1996. Development of fungi below ground in association with plants growing in disturbed and undisturbed soils. Soil Biol. Biochem. 28, 263-269.

Oscarson, P., Ingemarsson, B., Ugglas, M., Larsson, C.M., 1987. Short-term studies of $\mathrm{NO}_{3}{ }^{-}$uptake in Pisum using ${ }^{13} \mathrm{NO}_{3}{ }^{-}$. Planta $170,550-555$.

Rennenberg. H., Schneider, S., Weber, P. 1996. Analysis of uptake and allocation of nitrogen and sulfur compounds by trees in the field. J. Exp. Bot. 47, 1491-1498.

Rincon, M., Hanson, J.B., 1986. Controls on calcium ion fluxes in injured or shocked corn root cells: importance of proton pumping and cell membrane potential. Physiol. Plant. 67, 576-583.

Rothstein, D.E., Zak, D.R., Pregitzer, K.S., Curtis, P.S., 2000. Kinetics of nitrogen uptake by Populus tremuloides in relation to atmospheric $\mathrm{CO}_{2}$ and soil nitrogen availability. Tree Physiol. 20, 265-270.

Rygiewicz, P.T., Bledsoe, C.S., 1986. Effects of pretreatment conditions on ammonium and nitrate uptake by Douglas-fir seedlings. Tree Physiol. 1, 145-150.

Rygiewicz, P.T., Bledsoe, C.S., Zasoski, R.J., 1984. Effects of ectomycorrhizae and solution $\mathrm{pH}$ on $\left[{ }^{15} \mathrm{~N}\right]$ nitrate uptake by coniferous seedlings. Can. J. For. Res. 14 893-899.

SAS Institute, 1985. SAS User's Guide. SAS Institute, Cary.

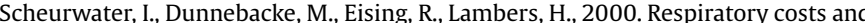
rate of protein turnover in the roots of a fast-growing (Dactylis glomerata L.) and a slow-growing (Festuca ovina L.) grass species. J. Exp. Bot. 51, 1089-1097.

Scholberg, J.M.S., Parsons, L.R., Wheaton, T.A., McNeal, B.L., Morgan, K.T., 2002. Soil temperature, nitrogen concentration, and residence time affect nitrogen uptake efficiency in citrus. J. Environ. Qual. 31, 759-768.

Smith, S.E., Read, D.J., 1997. Mycorrhizal Symbiosis. Academic Press, San Diego, 605 pp. 